\title{
Penyimpangan Nilai-Nilai Dasar Pancasila pada Kehidupan Bermasyarakat dan Bernegara
}

\author{
Hanifah Budi Novitasari ${ }^{1}$ \\ Universitas Pembangunan Nasional "Veteran" Yogyakarta \\ 114210073@upnyk.ac.id
}

\begin{abstract}
ABSTRAK
Penyimpangan akan nilai dasar yang terkandung dalam Pancasila sampai detik ini masih sering terjadi di sekitar kita. Penyelenggaraannya terkadang masih tidak sesuai dengan isi dan hakikat yang seharusnya. Tidak sedikit juga masyarakat yang tidak sepenuhnya mengerti akan penting dan betapa fatalnya penyimpangan akan nilai-nilai dasar pancasila ini bila terjadi. Kesatuan negara menjadi salah satu hal yang terdampak jika penyimpangan akan nilai pancasila di Indonesia terus terjadi. Penelitian yang dilakukan bertujuan untuk memberikan gambaran sekaligus kesadaran akan pentingnya hal tersebut dan apa hal yang harus dilakukan masyarakat dan negara untuk mengatasinya menggunakan metode analisis kualitatif dengan pendekatan deskriptif analisis yang berfokus pada kasus ketika penyelidikan dilakukan, memproses dan menganalisis temuan, dan menarik kesimpulan atas kasus tersebut. Hasil penyelidikan dan analisis menunjukan bahwa masih banyak sekali kasus-kasus dan konflik akan penyimpangan nilai pancasila dalam kehidupan bermasyarakat serta bernegara pada setiap niali-nilai dasar sila-sila dalam pancasila sehingga harus disikapi dengan lebih tegas lagi oleh seluruh warga negara Indonesia.
\end{abstract}

Kata Kunci: Penyimpangan, Pancasila, nilai-nilai dasar, konflik, masyarakat.

\begin{abstract}
ABSTRAK
Deviations from the basic values contained in Pancasila to this day still often occur around us. The implementation of it are sometimes not in accordance with the content and nature that it should be. There are still a lot of people who do not fully understand the importance and how fatal this deviation from the basic values of Pancasila would be if it occurred. The unity of the country is one of the things that will be affected if deviations from the values of Pancasila in Indonesia continues to occur. This study aims to provide an overview as well as awareness about the importance of this and what to do using qualitative analysis methods with a descriptive analysis approach that focuses on the case when the investigation is carried out, processes and analyzes the findings, and draws conclusions on the case. the. The results of the investigation and analysis show that there are still many cases and conflicts regarding the deviation of Pancasila values in the life of society and the country in each of the basic values that precepts in Pancasila so that it must be addressed more firmly by the citizens of Indonesia.
\end{abstract}

Keywords: Deviations, Pancasila, basic values, conflict, society.

\section{PENDAHULUAN}

Dalam kehidupan bernegara setiap manusia, terdapat aturan atau norma yang harus dipatuhinya sebagai warga negara. Tiap negara pasti memiliki acuan norma dan aturan yang berbeda-beda, tetapi untuk norma yang mengatur kehidupan bangsa Indonesia sendiri adalah Pancasila dan Undang-Undang Dasar Negara Republik Indonesia Tahun 1945. Seiring dengan berkembangnya pola pikir masyarakat di 
Indionesia, pola pikir akan implementasi nilai-nilai Pancasila itu sendiri juga terpengaruhi, secara postif maupun negatif.

Pancasila sendiri merupakan dasar pedoman untuk menjalankan kehidupaan bemasyarakat dan bernegara (Novita Eleanora, 2019). Dalam pancasila termuat cita-cita, ide-ide, juga gagasan-gagasan yang ingin di capai bangsa indonesia. Tetapi apakah nilai-nilai dalam pancasila tersebut sudah sesuai dengan keadaan saat ini? Kemajuan peradaban yang terjadi tentunya menjadi sebuah tantangan bagi Pancasila untuk terus berkembang di tengahtengahnya. Selama perkembanganya, telah terjadi beberapa insiden yang dianggap dapat mengancam keutuhan NKRI dan salah satunya adalah bagaimana rakyat papua mendirikan Organisasi Papua Merdeka dengan tujuan untuk memisahkan diri dengan Indonesia (Anwar Ilmar:2017) Insiden tersebut menunjukan bahwa telah terjadi penyimpangan nilai dasar pancasila yaitu nilai ketuhanan, Kemanusiaan, Persatuan, Kerakyatan, dan Keadilan.

\section{HASIL DAN PEMBAHASAN}

Nilai-nilai Pancasila merupakan hal yang sangat krusial untuk diimplementasikan setiap warga negara Indonesia dalam kehidupan pribadi, lingkungan keluarga dan masyarakat, maupun bangsa negara karena Pancasila bukan hanya pandangan dan pola hidup bangsa Indonesia, tetapi juga menjadi dasar negara Indonesia. Dasar negara suatu negara berlaku untuk mengatur segala perjanjian

\section{METODE}

Metode yang digunakan dalam penelitian ini adalah metode kualitatif. Menurut (Creswell, 1998:15), penelitian kualitatif merupakan salah satu proses penelitian dan pemahaman yang berdasarkan pada metodologi yang menyelidiki suatu fenomena sosial dan masalah manusia. Metode kualitatif ini meninjau tentang penyimpangan nilai-nilai dasar pancasila denga pendekatan deskriptif analisis data. Adapun pengertiannya menurut (Sugiono: 2009; 29), pendekatan secara deskriptif analisis merupakan suatu metode yang berfungsi menggambarkan atau memberi deskripsi terhadap objek yang diteliti melalui data atau sampel yang sudah terkumpul sebagaimana adanya tanpa melakukan analisis dan menciptakan konklusi yang berlaku untuk umum. Metode ini berfokus pada kasus ketika penyelidikan dilakukan, memproses dan menganalisis temuan, dan menarik kesimpulan. Data yang diperoleh terkumpul dari pencarian data yang bersumber dari jurnal-jurnal.

yang dibentuk dalam suatu negara. Negara tanpa dasar negara sama dengan negara tanpa pedoman dalam mengatur kehidupan bernegara. Hal ini dapat menyebabkan kebingungan karena negara tidak memiliki arah dan tujuan yang jelas.

Nilai-nilai dasar tersebut merupakan inti dari Pancasila: ketuhanan, kemanusiaan, persatuan, kewarganegaraan, dan keadilan. Karena nilai-nilai dasar merupakan intisari dari pelajaran Pancasila yang bersifat 
universal, maka nilai-nilai dasar memiliki kandungan tujuan, cita-cita, dan nilai yang baik dan benar yang ideal. Nilai-nilai dasar ideologi ini terdapat di dalam salah satu norma dasar dan termasuk dalam hukum tertinggi di Indonesia, Pembukaan UUD 1945.. Sebagai ideologi terbuka, nilai dasar inilah yang bersifat tetap dan juga karena pembukaan UUD 1945 memuat nilai-nilai dasar tersebut maka Pembukaan UUD 1945 juga memiliki sifat yang tetap dan melekat pada kelangsungan hidup negara. Nilai dasar tersebut kemudian dijabarkan dalam pasalpasal UUD 1945 yang di dalamnya terkandung lembaga- lembaga penyelenggara negara, hubungan antar lembaga penyelenggara negara beserta tugas dan wewenangnya.

Menurut Notonagoro (1967:28), rumusan isi pelajaran Pancasila sebagai dasar falsafah bangsa adalah :

1. Sila pertama, Ketuhanan Yang Maha Esa adalah ketuhanan yang berkemanusiaan, juga berpersatuan, berkerakyatan, dan berkeadilan sosial bagi seluruh rakyat Indonesia.

2. Sila kedua, Kemanusiaan yang adil dan beradab adalah kemanusiaan yang berketuhanan, berpersatuan, Berkerakyatan, dan berkeadilan sosial.

3. Sila ketiga, Persatuan Indonesia adalah persatuan yang berketuhanan, berkemanusiaan, berkerakyatan, dan berkeadilan sosial.

4. Sila keempat, Kerakyatan yang dipimpin oleh hikmah kebijaksanaan dalam permusyaratan/perwakilan adalah kerakyatan yang berketuhanan, berkemanusiaan, berpersatuan Indonesia, dan berkeadilan sosial.

5. Sila kelima, Keadilan sosial bagi seluruh rakyat Indonesia adalah keadilan sosial yang berketuhanan, berkemanusiaan, berkerakyatan, dan yang berpersatuan Indonesia.

Dari rumus isi pancasila ini dapat diartikan bahwa pancasila memuat nilai-nilai dasar yang di dalamanya semua nilai-nilai tersebut saling memiliki kaitan antar satu dengan yang lainnya. Hal ini juga yang menegaskan pentingnya menerapkan nilainilai dasar pancasila tersebut di dalam lingkup kehidupan.

Meskipun begitu, selama ini pancasila yang dijadikan salah satu pedoman hidup bernegara tidak selalu terlaksanakan sesuai dengan isi dan hakikat yang seharusnya. Salah satu kendala mengapa pancasila belum terlaksana dengan baik adalah karena adanya ketidaksesuaian atau inkonsistensi antara nilai-nilai yang terkadung dalam nilai dasar pancasila.

Terdapat Banyak sekali konflikkonflik yang terjadi di bangsa dan negara ini, yang menjadi alasan mengapa adanya ketidaksesuaian nilai yang terkandung pada pancasila dengan realita di kehidupan bermasyarakat dan bernegara ini. Hal ini bisa dirasakan bahwa seiring berjalannya waktu, nilai-nilai Pancasila mulai perlahan luntur di tengah masyarakat Indonesia. 


\section{A. Penyimpangan Terhadap Nilai Dasar}

\section{Ketuhanan}

Pencerminan akan sikap toleransi antar umat beragama dan menjalankan perintah agama masing-masing adalah beberapa hal yang berperan besar dalam nilai dasar ketuhanan pada sila pertama pencasila yang berbunyi "ketuhanan yang maha esa". Tetapi sayangnya kejadian penyimpangan nilai ketuhanan pernah terjadi yaitu saat terjadinya perilaku radikal individu/kelompok atas nama agama. Mereka melakukan aksi pembunuhan yang tidak mencerminkan sikap toleran terhadap orang lain dan tidak sejalan dengan nilai ketuhanan dalam sila pertama. Seperti yang pernah terjadi ialah kasus bom bunuh diri yang serentak terjadi di 3 gereja di kota Surabaya, Jawa Timur pada tahun 2018 silam. Alasan dan tujuan awal para pelaku bom bunuh diri menurut (Wicaksono, 2018) yaitu memperjuangkan berdirinya Khilafah Islamiyah pada bumi Indonesia dan salah satu caranya dikenal dengan istilah berjihad, yang bahkan penafsiranya akan arti jihad juga di salah artikan. Padahal seharusnya wujud perilaku dari sila beserta niali dasar ini adalah menjalankan segala perintah oleh ajaran agamanya masing-masing dan yang pastinya tidak merugikan orang lain.

\section{B. Penyimpangan Terhadap Nilai Dasar}

\section{Kemanusiaan}

Perilaku yang seharusnya diwujudkan dalam nilai dasar kemanusiaan ini adalah dapat menghargai derajat dan kedudukan orang lain, saling mencintai, saling mencintai, dan mampu mencapai kondisi harmonis dalam kehidupan bermasyarakat. Jika diperhatikan, penyimpangan terhadap nilai-nilai kemanusiaan di Indonesia merupakan salah satu penyimpangan nilai dasar yang cukup marak terjadi. Salah satu contohnya adalah bagaimana beberapa oknum di pemerintahan sering menggunakan posisinya untuk berperilaku semena-mena terhadap masyarakat dan menganggap masyarakat berada di "level" yang berbeda dengan dirinya. Penyalagunaan wewenang ini merupakan salah satu bentuk dari penyimpangan nilai kemanusiaan karena tidak sejalan dengan bunyi sila kedua yaitu "kemanusiaan yang adil dan beradab".

\section{Penyimpangan Terhadap Nilai Dasar Persatuan}

Nilai dasar yang ada dalam sila ketiga yang berbunyi "persatuan indonesia" ini menekankan akan perwujudan sikap persatuan antar masyarakat indonesia seperti contohnya sebagai masyarakat bangsa Indonesia harus bisa saling bekerja sama, bergotong royong, dan memiliki jiwa rela berkorban yang ditanamkan di dalam diri masing-masing. Tetapi sampai saat ini pun masih terjadi konflik-konflik yang penyimpangi nilai dasar persatuan ini seperti terjadinya Peristiwa OPM (Gerakan Papua Merdeka) yang sudah ada sejak tahun 1965. Tujuan dari adanya gerakan ini adalah untuk meninggalkan dan memsiahkan diri dari menjadi bagian negara di Republik Indonesia. Keinginan untuk membentuk negara sendiri merupakan sebuah indikasi tentang bagaimana pengimplementasian 
nilai-nilai dasar pancasila ini belum sepenuhnya terlaksanakan. Tidak hanya itu, perilaku-perilaku diskriminatif terhadap orang lain juga merupakan salah satu bentuk penyimpangan nilai dasar persatuan.

\section{Penyimpangan Terhadap Nilai Dasar}

\section{Kerakyatan}

Nilai dari sila keempat yang berbunyi "kerakyatan yang dipimpin oleh hikmat kebijaksanaan dalam permusyawaratan perwakilan" Artinya, kedaulatan ada di tangan rakyat. Semua warga negara berhak memilih wakilnya, dan semua masyarakat memiliki kedudukan yang sama. Selain itu sila ini juga membahas tentang musywarah yang mufakat dalam setiap kegiatan dalam melaksanakan keputusan. Hal ini juga berkesinambungan dengan bentuk pemerintahan indonesia yang menganut demokrasi. Maka dari itu perliaku yang seharusnya diwujudkan oleh masyarakat salah satunya adalah ikut serta dalam pemilihan umum dan bagaimana selama ini masih banyak masyarakat yang melakukan tindakan golput dimana ia tidak berpartisipasi dalam pemilihan umum. Padahal mengikuti pemilihan suara adalah hal yang penting karena itulah yang akan menentukan masa depan pemimpinpemimpin negara ini kedepannya. Seharusnya setiap warga negara Indonesia wajib ikut serta untuk menyuarakan suaranya melalui pemilihan umum ini karena setiap rakyat memang berhak dan agar musyawarah terlaksanakan dengan benar.

\section{E. Penyimpangan Terhadap Nilai Dasar} Keadilan

Penyimpangan tentang nilai dasar keadilan di indonesia merupakan salah satu yang sering ditemui. Nilai dasar keadilan pada sila kelima, "keadilan sosial bagi seluruh rakyat indonesia" secara jelas menetapkan keadilan yang menyeluruh dan merata bagi seluruh rakyat Indonesia. Oleh karena itu, reifikasi tindakan yang diambil untuk sanksi dan tindakan yang sesuai dengan hukum yang berlaku harus terlepas dari posisi dan latar belakang. Tetapi sayangnya di indonesia sendiri masih banyak terjadi kasus-kasus seperti penahanan seseorang yang mencuri kakao seharga 2000 rupiah dan pencurian satu buah semangka, dan tersangka tersebut ditahan oleh polisi selama 2 bulan, dan terancam dipidana selama 5 tahun. Sedangkan ini sangat berbading terbalik dengan kasus pejabat yang memakan uang negara yang jumlahnya sangat banyak sekali sampai bermilyaran, tetapi tidak segera diselidiki, dan hanya mendapatkan penahanan selama 1-2 tahun. Hal-hal seperti ini sangat menyimpang dengan nilai-nilai dasar pancasila terlebih lagi dalam nilai keadilan.

\section{SIMPULAN}

Kebangkitan Pancasila dalam kehidupan bermasyarakat, berbangsa, dan berbangsa harus dilakukan secara konsisten. Pendidikan karakter perlu ditanamkan pada masyarakat agar dapat terbentuk karakter/karakter yang baik sesuai dengan 
nilai-nilai yang ada dalam Pancasila. Pelajari dan didik tentang kepribadian Anda di bidang pendidikan. Pendidikan kepribadian ini akan membantu embantu dalam perkembangan dan pembentukan kepribadian serta peradaban bangsa yang akan memberikan kontribusi bagi mencerdaskan kehidupan bangsa Indonesia. Instansi pendidikan dan pemerintahan perlu menerapkan nilai-nilai Pancasila menjadi cahaya dan pedoman untuk mencapai tujuan negara Indonesia. Dengan menerapkan nilainilai Pancasila, perubahan mendasar akan membawa masyarakat, bangsa, dan negara kita kembali pada identitasnya sebagai bangsa besar yang berideologi nilai luhur Pancasila dalam kehidupan sehari-hari. Kebangkitan nilai-nilai Pancasila harus dilakukan karena dilandasi oleh inkonsistensi yang ada antara cita-cita luhur Pancasila dengan realitas penegakan hukum dalam kehidupan dewasa ini. Nilai-nilai Pancasila yang terkandung dalam Pancasila dapat dengan jelas menjelaskan cita-cita negara Indonesia.

\section{DAFTAR PUSTAKA}

Novita Eleanora, F. (2019). Pancasila Sebagai Norma Dasar Dalam Sistem Hukum Indonesia. ADIL: Jurnal Hukum, 3(1), 141.

Wicaksono, H. (2018). Analisis Kriminologis: Serangan Bom Bunuh Diri di Surabaya. Deviance: Jurnal Kriminologi, 2(2), 88-101. Suraya. (2015). Pancasila dan ketahanan jati diri bangsa. Bandung: PT Refika

Aditama

Ilmar, A. (2017). Radikalisme Gerakan BerbasisEtnis: KasusOrganisasi Papua Merdeka. The Indonesian Journal of Public Administration (IJPA), 3(2), 72-87

Creswell, J. W. (1998). Qualitatif Inquiry and Research Design. Sage Publications, Inc: California

Sugiyono. (2009). Metode Penelitian Pendidikan Pendekatan Kuantitatif, Kualitatif, dan R\&D. Bandung : Alfabeta

Notonagoro. (1967). Beberapa Hal Mengenai Falsafah Pantjasila. Pantjuran Tujuh. Jakrata.

Agus, A. (2016). Relevansi Pancasila Sebagai Ideologi terbuka di Era Reformasi. Jurnal Office, 2(2).

Hakim, A., \& Dinie, D. (2021). Pentingnya Implementasi Nilai Pancasila Agar Tidak Terjadi Penyimpangan Dalam Masyarakat Luas. Jurnal Kewarganegaraan, 5(1).

Pahlevi, F. S. (2016). Revitalisasi Pancasila Dalam Penegakan Hukum yang Berkeadilan di Indonesia. Jurnal STAIN Ponorogo.

Wardana, Joyo dkk. (2021). Sosialisasi Pentingnya Nilai-nilai Pancasila. DedikasiMU (Journal of Community Service), 3(1)

\section{UCAPAN TERIMA KASIH}

Puji syukur saya ucapkan pada Allah SWT. Yang telah memberi kelancaran pada 
Jurnal Pancasila dan Bela Negara Vol.1 No. 2, September 2021, hal.8-14.

E-ISSN:2775-5886

saya unutk menulis tulisan ini. Ucapan terimakasih juga saya berikan kepada seluruh rekan saya yang telah membantu saya dan menemani saya selama proses penulisan tulisan ini. Saya berharap Semoga kedepannya tulisan ini dapat memberi manfaat bagi pembacanya.

\section{TENTANG PENULIS}

Hanifah Budi Novitasari, lahir di kota industri kecil Bontang di Kaliamantan Timur pada tanggal 13 November 2003 dan saat ini tengah menjalani pendidikan di Universitas Pembangunan Nasional "Veteran" Yogyakarta. 